\title{
Molecular Manipulations of a Utility Nitrogen-Heterocyclic Carbene by Sodium Magnesiate Complexes and Transmetallation Chemistry with Gold Complexes
}

\author{
Alberto Hernán-Gómez, Marina Uzelac, Sharon E. Baillie, David R. Armstrong, Alan R. Kennedy, M. \\ Ángeles Fuentes, and Eva Hevia*
}

Dedicated to Professor Dietmar Stalke on the occasion of his $60^{\text {th }}$ birthday

\begin{abstract}
Expanding the scope and applications of anionic $\mathrm{N}$ heterocyclic carbenes (NHCs), a novel series of magnesium NHC complexes is reported using a mixed-sodium-magnesium approach. Sequential reactivity of classical imidazol-2-ylidene carbene IPr with $\mathrm{NaR}$ and $\mathrm{MgR}_{2}\left(\mathrm{R}=\mathrm{CH}_{2} \mathrm{SiMe}_{3}\right)$ affords $\left[(\mathrm{THF})_{3} \mathrm{Na}\left(\mu-\mathrm{IPr}^{-}\right) \mathrm{MgR}_{2}(\mathrm{THF})\right]$ (2) $\left[\mathrm{IPr}^{-}=: \mathrm{C}\left\{\left[\mathrm{N}\left(2,6-\mathrm{Pr}_{2} \mathrm{C}_{6} \mathrm{H}_{3}\right)\right]_{2} \mathrm{CHC}\right]\right.$ containing an anionic $\mathrm{NHC}$ ligand, whereas surprisingly sodium magnesiate $\left[\mathrm{NaMgR}_{3}\right]$ fails to deprotonate $\mathrm{IPr}$ affording instead the redistribution coordination adduct $\left[\mathrm{IPr}_{2} \mathrm{Na}_{2} \mathrm{MgR}_{4}\right]$ (1). Compound 2 undergoes selective C2methylation when treated with MeOTf furnishing novel abnormal $\mathrm{NHC}$ complex [\{alPr$\left.\left.{ }^{\mathrm{Me}} \mathrm{MgR}_{2}\right\}_{2}\right](\mathbf{3})$. Dissolving $\mathbf{3}$ in THF led to the dissociation of this complex into $\mathrm{MgR}_{2}$ and $a \mathrm{Pr}^{\mathrm{Me}}$ with the latter isomerizing to the olefinic $\mathrm{NHC} \mathrm{IPr}=\mathrm{CH}_{2}$. The ability of $\mathbf{2}$ and $\mathbf{3}$ to transfer their anionic and abnormal $\mathrm{NHC}$ ligands respectively to $\mathrm{Au}(\mathrm{I})$ metal fragments has been investigated allowing the isolation and structural characterization of $\left[\mathrm{RAu}\left(\mu-\mathrm{Pr}^{-}\right) \mathrm{MgR}(\mathrm{THF})_{2}\right]$ (4) and [alPrMeAuR] (5) respectively. In both cases transfer of an alkyl $R$ group is observed. However while $\mathbf{3}$ can also transfer its abnormal $\mathrm{NHC}$ ligand to give $\mathbf{5}$, in $\mathbf{4}$ the anionic $\mathrm{NHC}$ still remains coordinated to $\mathrm{Mg}$ via its $\mathrm{C} 4$ position, whereas the $\{\mathrm{AuR}\}$ fragment occupies the $\mathrm{C} 2$ position previously filled by a donor-solvated $\left\{\mathrm{Na}(\mathrm{THF})_{3}\right\}^{+}$cation.
\end{abstract}

\section{Introduction}

Since starting as mere laboratory curiosities and phosphine alternatives, $\mathrm{N}$-heterocyclic carbenes (NHCs), in particular imidazol-2-ylidenes, have developed into rising stars of the chemical world. Their applications as versatile ligands are now widespread, spanning from transition metal catalysis, ${ }^{[1]}$ small molecule activation, ${ }^{[2]}$ organocatalysis, ${ }^{[3]}$ to stabilisation of lowvalent main group complexes, ${ }^{[4]}$ to name just a few. A signature feature of these strong $\sigma$-donor ligands is their ability to be finetuned both sterically and electronically, which can be accomplished by modifying the substituents on their $\mathrm{N}$ atoms or their olefinic backbones. ${ }^{\left[{ }^{5]}\right.}$ While typically, the carbene centre is

[a] Dr. A. Hernán-Gómez, Dr. M. Uzelac, Dr. S. E. Baillie, Dr. D. R. Armstrong, Dr. A. R. Kennedy, Dr. M. Á. Fuentes, Prof. E. Hevia WestCHEM, Department of Pure and Applied Chemistry University of Strathclyde

295 Cathedral Street, Glasgow, G1 1XL (UK)

E-mail: eva.hevia@strath.ac.uk

Supporting information for this article is given via sandwiched between the two nitrogen atoms (C2 position) enabling $\pi$-donation by both adjacent $\mathrm{N}$-heteroatoms into the empty $p_{\pi}$ orbital of the carbene, the expansion of their coordination chemistry have created a different type of $\mathrm{NHC}$ complex, where the imidazole ring binds to the metal centre through its backbone. These less stabilised carbenes, where there is only one $\mathrm{N}$-atom adjacent to their carbenic carbon, have been termed as abnormal (or mesoionic) NHCs (commonly written as aNHCs). ${ }^{[6,7]}$ Another important class of carbenes that has recently emerged and continues to thrive over the past few years is that of anionic NHCs, resulting from the metallation of the unsaturated backbone of the imidazol-2-ylidene ring. ${ }^{[8,9]} \mathrm{A}$ key landmark in this field is Robinson's lithiation of $\mathbf{I P r}(\mathbf{I P r}=1,3-$ bis(2,6-di-isopropylphenyl)-imidazol-2-ylidene) by ${ }^{n} \mathrm{BuLi}$ which affords a unique polymeric structure where the lithium atoms are connected by anionic NHC bridges through their normal $\mathrm{C} 2$ and C4 positions. ${ }^{[9]}$ Contrasting with this reactivity, moving to the diagonal neighbour of ${ }^{n} \mathrm{BuLi}$ in the periodic table, when ${ }^{n} \mathrm{Bu}_{2} \mathrm{Mg}$ is used, the deprotonation process is completely inhibited, affording instead a normal coordination adduct. ${ }^{[10]}$ Furthermore, there are several literature examples of structurally defined $\mathrm{NHC}$ complexes containing $\mathrm{Mg}$ amides, Grignard reagents and other dialkylmagnesium compounds. ${ }^{[10-13]}$ Nevertheless, highlighting the power of bimetallic alliances in s-block metal chemistry, our collaborative work with Mulvey and O'Hara has recently shown that by pairing $\mathrm{Mg}$ with $\mathrm{Na}$ within the same molecule it is actually possible to promote the magnesiation of IPr ${ }^{[14]}$ Interestingly, these studies using heteroleptic magnesiates which combine the highly basic amido group TMP (TMP = 2,2,6,6tetramethylpiperidide) with butyl ligands, have revealed that that the regioselectivity of these reactions is finely controlled by the structure of the bimetallic base employed, enabling IPr to be metallated at its backbone, but also at the para position of one of its substituent aromatic arms. On the other hand, using tris(amido) sodium magnesiate $\left[\mathrm{NaMg}(\mathrm{HMDS})_{3}\right] \quad(\mathrm{HMDS}=$ 1,1,1,3,3,3-hexamethyldisilazide), Hill has reported formation of coordination adducts, where two carbenes coordinate to $\mathrm{Na}$, forming charge separated species $\left[\left\{\mathrm{NaIPr}_{2}\right\}^{+}\left\{\mathrm{Mg}(\mathrm{HMDS})_{3}\right\}^{-}\right]^{[15]}$ Intrigued by these contrasting reactivities, and aiming to expand the scope and applications of anionic NHCs in s-block metal chemistry, here we report a novel series of magnesium compounds containing neutral, anionic and abnormal NHC ligands using a mixed-sodium-magnesium approach. The ability of some of these novel magnesium/magnesiate systems to act as transfer reagents towards transition metal complexes has 
also been assessed by studying their reactivity towards $\mathrm{Au}(\mathrm{I})$ complexes.

\section{Results and Discussion}

Bimetallic Approaches for IPr metallation: Magnesiate versus Sequential Single-metal Reactivities

We started by investigating the reactivity of IPr with sodium magnesiate $\mathrm{NaMgR}_{3} \quad\left(\mathrm{R}=\mathrm{CH}_{2} \mathrm{SiMe}_{3}\right)$. This ate was first developed by our group ${ }^{[16]}$ and has already shown great promise as an efficient precatalyst in hydroamination reactions of isocyanates and carbodiimides. ${ }^{[17,18]}$ Performing this reaction at room temperature in a hexane/benzene non-Lewis basic solvent mixture, using equimolar amounts of $\mathrm{IPr}$ and $\mathrm{NaMgR}_{3}$ led to the isolation of sodium tetra(alkyl) magnesiate $\left[\mathrm{IPr}_{2} \mathrm{Na}_{2} \mathrm{MgR}_{4}\right]$ (1) as colourless crystals in a $13 \%$ yield (note that the maximum possible yield for this reaction is $50 \%$, Scheme $1 \mathrm{a}$ ). This can be regarded as a higher order magnesiate having a 2:1, instead 1:1, $\mathrm{Na}: \mathrm{Mg}$ stoichiometry. ${ }^{[19]}$
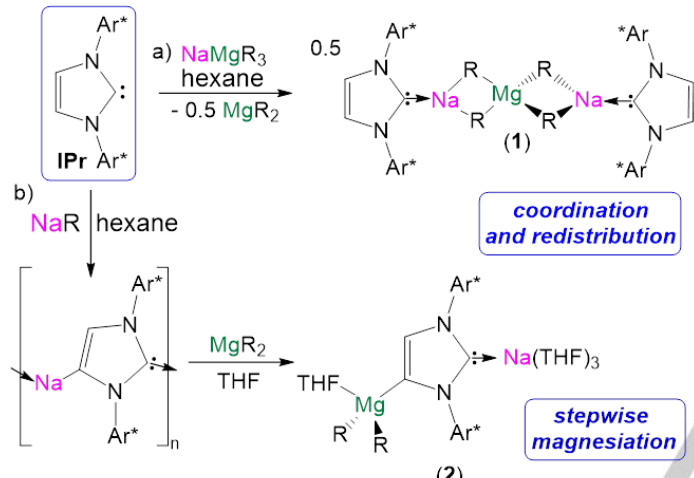

$\mathrm{R}=\mathrm{CH}_{2} \mathrm{SiMe}_{3}$

Scheme 1. Synthesis of 1 and 2.

X-ray crystallographic studies established the molecular structure of 1 to be a discrete contacted ion pair (CIP) structure (Figure 1). Isolation of $\mathbf{1}$ reveals that while $\mathrm{NaMgR}_{3}$ does not seem basic enough to promote the deprotonation of IPr, the carbene must induce a redistribution process to the higher order magnesiate complex with the $2: 1 \mathrm{Na} / \mathrm{Mg}$ ratio. A tetracoordinated distorted tetrathedral $\mathrm{Mg}$ atom occupies the centre of the trinuclear bimetallic unit with four R-groups forming bridges with outer IPr-capped sodium atoms in an almost linear arrangement along $\mathrm{C} 1 \cdots \mathrm{Na} 1 \cdots \mathrm{Mg} 1 \cdots \mathrm{Na} 2 \cdots \mathrm{C} 44$ plane, evidenced by $\mathrm{C}_{1} \cdots \mathrm{Na} 1 \cdots \mathrm{Mg} 1=175.09(15)^{\circ}, \mathrm{Na} 1 \cdots \mathrm{Mg} 1 \cdots \mathrm{Na} 2=176.32(9)^{\circ}$ and $\mathrm{Mg} 1 \cdots \mathrm{Na} 2 \cdots \mathrm{C} 44=171.17(16)^{\circ}$ angles. The four $\mathrm{Mg}-\mathrm{C}$ bond distances are almost identical, with an average value of $2.259 \AA$, being in excellent agreement with those reported for the related magnesiate complex $\left[\left(\mathrm{SIMes}_{2} \mathrm{Li}_{2} \mathrm{MgR}_{4}\right]\right.$ resulting from the reaction of the saturated NHC SIMes (SIMes $=1,3-$ bis- $(2,4,6-$ trimethylphenyl)imidazolidin-2-ylidene) with a 2:1 mixture of LiR and $\mathrm{MgR}_{2}{ }^{[20]}$ Each $\mathrm{Na}$ exhibits a planar three-coordinate geometry made up by coordination to two alkyl groups and one IPr molecule.

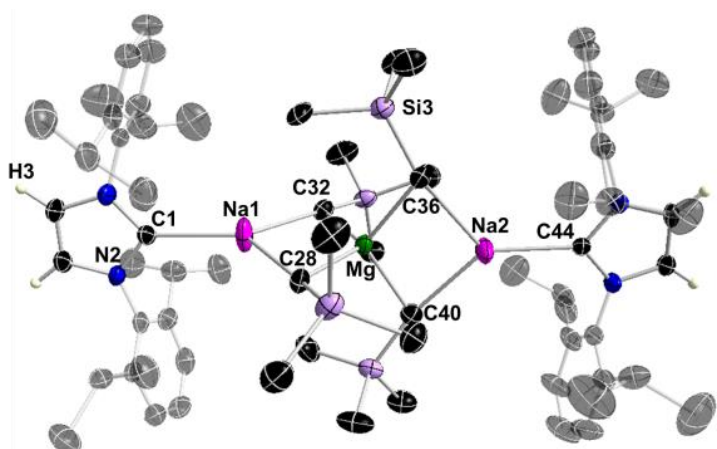

Figure 1. Molecular structure of $\mathbf{1}$ with displacement ellipsoids drawn at the $50 \%$ probability level. Hydrogen atoms except those on the imidazole ring have been omitted for clarity. The unit cell of $\mathbf{1}$ contains two crystallographically independent molecules with identical connectivity.

The $\mathrm{Na}-\mathrm{C}_{\text {carbene }}$ distances (average $2.430 \AA$ ) are within the same range as those previously witnessed by Hill for $\left[\left\{\mathrm{Na}(\mathrm{IPr})_{2}\right\}^{+}\left\{\mathrm{Mg}(\mathrm{HMDS})_{3}\right\}^{-}\right][2.439(6) \text { and } 2.452(2) \AA]^{[15]}$ and noticeably shorter than the $\mathrm{Na}-\mathrm{C}_{\text {alkyl }}$ bonds in 1 [range: 2.506 (5)$2.568(6) \AA]$. The elongation of the latter can be rationalized considering the ancillary nature of these $\mathrm{Na}-\mathrm{C}$ bonds when compared with the $\mathrm{Mg}-\mathrm{C}$ bonds that anchor the magnesiate framework, to which the $\{\mathrm{Na}(\mathrm{IPr})\}^{+}$fragments are affixed. [21]

${ }^{1} \mathrm{H}$ and ${ }^{13} \mathrm{C}$ NMR spectroscopic studies of 1 in in $\mathrm{C}_{6} \mathrm{D}_{6}$ solution are consistent with the retention of its structure in the solid state, displaying only one set of resonances for the Dipp and R groups. The persistence of IPr coordination to $\mathrm{Na}$ is best indicated by an informative resonance at $202.9 \mathrm{ppm}$ in the ${ }^{13} \mathrm{C}$ NMR spectrum at a similar chemical shift to those previously found in other $\mathrm{Na}$ NHC complexes. ${ }^{[14,15,22,23]}$

While redistribution processes on magnesiate chemistry have been previously noted, ${ }^{[24]}$ this is as far as we can ascertain the first one induced by an $\mathrm{N}$-heterocyclic carbene. Furthermore, previous attempts trying to prepare and isolate solvent free $\left[\mathrm{Na}_{2} \mathrm{MgR}_{4}\right]$ had proved unsuccessful leading instead to the isolation of the relevant triorganomagnesiate $\left[\mathrm{NaMgR}_{3}\right]$ and $\mathrm{NaR}{ }^{\left[{ }^{[16]}\right.}$ Here, by introducing $\mathbf{I P r}$, an alternative redistribution process on $\mathrm{NaMgR}_{3}$ is activated, where a putative [IPrNaMgR complex evolves into $\mathbf{1}$ and $\mathrm{MgR}_{2}$. The lack of metallation of IPr, and its preference to act as a neutral donor instead, contrast with our previous studies using heteroleptic sodium magnesiates ${ }^{[14]}$ which combine TMP and Bu groups and seem to be more aligned with Hill's formation of coordination adducts when using $\left[\mathrm{NaMg}(\mathrm{HMDS})_{3}\right]^{\left[{ }^{[15]}\right.}$

This prompted us to try a stepwise approach, by reacting sequentially the single components of $\mathrm{NaMgR}_{3}$. This strategy relies on the ability of $\mathrm{NaR}$ to metallate the $\mathrm{NHC}$ to form a sodium anionic $\mathrm{NHC}$ which in turn can undergo transmetallation to a lower polarity metal fragment ${ }^{[25]}$ and it has been recently successfully applied by us for the synthesis of novel sodium ferrate $^{[21]}$ and sodium gallate ${ }^{[23]}$ complexes containing anionic $\mathrm{NHCs}$. Thus, by treating IPr with a molar equivalent of $\mathrm{NaR}$ followed by the addition of $\mathrm{MgR}_{2}$ and THF, heteroleptic $\left.\left[(\mathrm{THF})_{3} \mathrm{Na}\left(\mu-\mathrm{IPr}^{-}\right) \mathrm{MgR}_{2}(\mathrm{THF})\right\}\right] \quad(\mathbf{2}) \quad\left[\mathrm{IPr}^{-} \quad=\quad \mathrm{C}\{[\mathrm{N}(2,6-\right.$ 
$\left.\left.\mathrm{Pr}_{2} \mathrm{C}_{6} \mathrm{H}_{3}\right)\right]_{2} \mathrm{CHC}$ ] was obtained in a $58 \%$ isolated yield (Scheme 1b).]

X-ray crystallisation analysis established a CIP structure of $\mathbf{2}$, however, this time the carbene has been incorporated as an anionic ligand simultaneously employing its C2 and C4 coordination sites. Witnessing the indirect magnesiation process, the Mg-centre is coordinated to the abnormal C4 position of IPr, preserving its two alkyl groups and completing its coordination sphere via a single molecule of THF, whilst the tris(THF)solvated $\mathrm{Na}$-ion is bound to the normal $\mathrm{C} 2$ position (Figure 2). The Na- $\mathrm{C}_{\text {carbene }}$ (i.e. C1 in Fig 2) bond distance of 2.468(3) $\AA$ is comparable, but on the shorter end to previously reported $\mathrm{Na}-\mathrm{C}$ bond distances in related bimetallic complexes containing a $\left\{\mathrm{Na}(\mathrm{THF})_{3}\right\}^{+}$fragment bonded to the $\mathrm{C} 2$-site of an anionic IPr ligand, such as $\mathrm{Na} / \mathrm{Zn}(2.501(3) \AA)\left({ }^{[26]} \mathrm{Na} / \mathrm{Fe}(2.510(4) \AA)^{[22]}\right.$ and $\mathrm{Na} / \mathrm{Ga}(2.530(3) \AA)^{[23]}$ The Mg-C4 (i.e. C2 in Fig 2) distance of 2.210 (3) $\AA$ is only slightly elongated in comparison to the $\mathrm{Mg}$ $\mathrm{C}_{\text {alkyl }}$ bonds (average $2.182 \AA$ ) and within the same range to those found in the previous two examples of magnesiation of $\mathbf{I P r}$ using mixed TMP/Bu sodium magnesiates. ${ }^{[14]}$

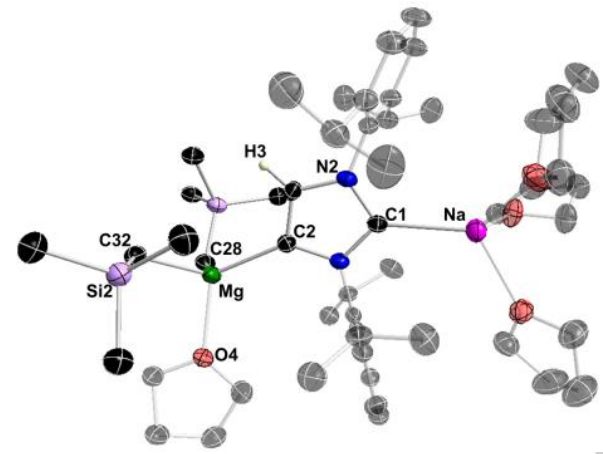

Figure 2. Molecular structure of $\mathbf{2}$ with displacement ellipsoids drawn at the $50 \%$ probability level. Hydrogen atoms except that on the imidazole ring and minor disorder in one molecule of THF have been omitted for clarity.

NMR studies of 2 in in $d_{8}$-THF solutions show that the $\mathrm{CH}\left(\mathrm{CH}_{3}\right)_{2}$ fragments of the Dipp groups resonate as two distinct sets of signals in the ${ }^{1} \mathrm{H}$ and ${ }^{13} \mathrm{C}$ NMR spectra as a result of the symmetry loss in IPr. The symmetry loss, as a result of the metallation in the backbone of the imidazole ring, is also mirrored by a large downfield resonance at $\delta=163.9 \mathrm{ppm}$ in the ${ }^{13} \mathrm{C}$ NMR spectrum for the $\mathrm{Mg}-\mathrm{C} 4$ group (versus $\delta=112.3 \mathrm{ppm}$ in the free IPr). In addition, the resonance assigned to the carbenic C2 is at 200.2 ppm supporting the C2 coordination of the anionic $\mathrm{NHC}$ to $\mathrm{Na} \cdot{ }^{[14,15,22,23]}$

Interestingly $\mathbf{2}$ is stable in solution without undergoing any redistribution process which contrast with previous examples of magnesiation using mixed metal systems where putative intermediate $(\mathrm{THF})_{3} \mathrm{Na}\left[(\mu-\mathrm{IPr}-) \mathrm{Mg}(\mathrm{TMP})_{2}\right]$ is postulated to be formed but rapidly evolves to [(THF) ${ }_{3} \mathrm{Na}(\mu$-IPr- $\left.) \mathrm{Mg}(\mathrm{THF})\left(\mathrm{IPr}^{-}\right)_{2}\right]$ which has be isolated and structurally defined. ${ }^{[14]}$

Accessing an abnormal NHC-Mg complex via electrophilic interception

Within main group chemistry, the number of complexes containing abnormal (or mesoionic) carbenes remains very limited, and for $\mathrm{Mg}$ the first examples containing this type of ligands were only reported in 2016 by Ghadwall. ${ }^{[2]}$ This method relies on the deprotonation of a C2-functionalised imidazolium salt using a Grignard reagent which affords [alPr${ }^{\mathrm{Ph}_{\mathrm{Mgl}}} \mathrm{OEt}_{2}$ ] $\left(\right.$ alPr $^{\mathrm{Ph}}=1,3$-bis (2,6-diisopropylphenyl)-2-phenyl-imidazol-4ylidene) which can then further undergo salt-metathesis and give the [alPrPh.Mg(HMDS) $)_{2}$ ] complex. Our previous attempt to access alPr. $\mathrm{MgR}_{2}$ by employing thermally induced isomerization of its normal analogue (i.e. IPr.MgR ${ }_{2},{ }^{[28]}$ a methodology that has been successful for complexes of $\mathrm{Ga}^{\left[{ }^{[28]}\right.} \mathrm{Fe}^{[29]} \mathrm{B}^{[2 \mathrm{a}]}$ or $\mathrm{Al}{ }^{[30]}$ and seems to be driven by the steric relief around the metal center, did not work even under forcing reaction conditions $(72 \mathrm{~h}$ at $100^{\circ} \mathrm{C}$ ). Having successfully isolated anionic NHC complex 2 we next pondered, if it could undergo selective electrophilic interception to render the relevant neutral aNHC-Mg complex, as this approach has already shown promising potential for other

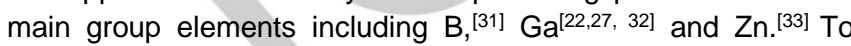
explore this possibility sodium magnesiate 2 was treated with a molar equivalent of $\mathrm{Me}_{3} \mathrm{SiCl}$ in toluene at $-30{ }^{\circ} \mathrm{C}$. Exchange of toluene in vacuo to a THF/hexane mixture led to isolation of free carbene IPr $^{\mathrm{TMS}}$ in $61 \%$ yield (Scheme $2 \mathrm{a}$ ), identified by comparison of its ${ }^{1} \mathrm{H}$ and ${ }^{13} \mathrm{C}$ NMR data to literature data. ${ }^{[34]}$

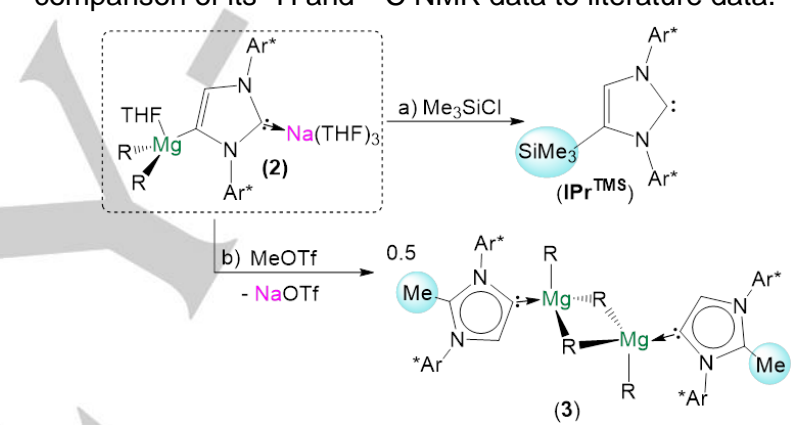

Scheme 2. Electrophilic interception of 2 with a) $\mathrm{Me}_{3} \mathrm{SiCl}$ affording free IPrTMS and b) MeOTf affording aNHC-Mg complex 3.

Surprisingly, in this reaction, despite the formation of this normal $\mathrm{NHC}$ ligands which could potentially coordinate to $\mathrm{Mg}$ to form an adduct (as observed for $\mathrm{IPrMgR}_{2}$ ), here $\mathrm{MgR}_{2}$ remains in solution, presumably forming a soluble donor-acceptor complex with THF. Formation of IPr $^{\text {TMS }}$ contrasts sharply with the reactivity described for the related mixed $\mathrm{K} / \mathrm{Ga}$ complex $\left[(\mathrm{THF})_{3} \mathrm{~K}(\mu-\mathrm{Pr}-) \mathrm{GaR}_{3}\right]^{[},{ }^{[23]}$ which comprises the same anionic $\mathrm{NHC}$, bridging between $\left\{\mathrm{K}(\mathrm{THF})_{3}\right\}^{+}$and $\mathrm{GaR}_{3}$ through its $\mathrm{C} 2$ and C4 positions respectively. Interestingly in this complex, silylation is observed at the $\mathrm{C} 2$ site, furnishing a neutral abnormal $\mathrm{NHC}$ gallium complex, where the Ga-C4 bond is preserved. Since the steric demands for both systems are similar, the different outcome of these reactions can be attributed to the significant polarization of the C4-Mg bond in 2 rendering it susceptible to electrophilic interception. Consistent with this interpretation, preferred C4-silylation has also been observed by Robinson for the reaction of lithiated IPr to afford IPr ${ }^{\text {TMS }}$. $^{[9]}$ Complementing these experimental studies, natural bond orbital (NBO) analysis of 2 indicates that most of the positive charge is carried primarily by the metals, showing significant dicationic character for the $\mathrm{Mg}$ atom (calculated natural charge of $\mathrm{Mg},+1.64$ ). Furthermore, as shown in Figure 3 , the three highest occupied molecular orbitals 
HOMO, HOMO-1 and HOMO-2 calculated for 2 correspond to the polarized $\mathrm{Mg}-\mathrm{C}$ bonding orbitals of the alkyl groups and the C4 of the anionic IPr ligand.
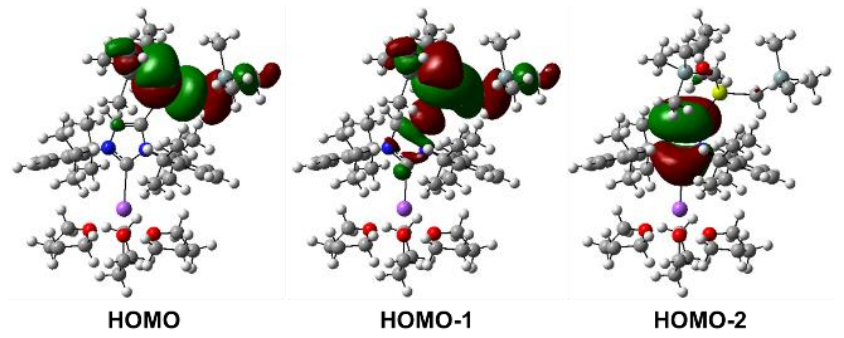

Figure 3. Calculated molecular orbitals HOMO, HOMO-1 and HOMO-2 of sodium magnesiate 2 .

Contrasting with this C4 selectivity, when 2 is treated with the strong methylating agent MeOTf, an electrophile that has previously being successfully used for several mixed-metal anionic NHC complexes, ${ }^{[22,28,33]}$ novel neutral abnormal complex [\{alPrMe MgR $\left.\}_{2}\right]$ (3) (alPr ${ }^{\mathrm{Me}}=$ 1,3-bis(2,6-diisopropylphenyl)-2methyl-imidazol-4-ylidene) is formed in a $30 \%$ isolated yield (Scheme $2 b$ ). It should be noted that this reaction needs to be carried out at $-78^{\circ} \mathrm{C}$ in toluene in order to control selectivity and stability of $\mathbf{3}$ (vide infra) and that the concomitant precipitation of a solid (presumably NaOTf) is also observed. Resulting from the selective C2-methylation of 2, complex 3 exhibits a dimeric structure in the solid state (Figure 4), with a central $\left\{\mathrm{Mg}_{2} \mathrm{R}_{4}\right\}$ core where the $\mathrm{Mg}$ centres are connected by two alkyl bridges and complete their coordination spheres by bonding terminally to the emergent abnormal NHC ligand. The bond length of the newly formed $\mathrm{C}_{2}-\mathrm{C}_{\mathrm{Me}}$ (i.e. C1-C28 in Figure 4) is consistent with the single bond while that of $\mathrm{Mg}-\mathrm{C} 4$ (i.e. $\mathrm{C} 2$ in Figure 4) bond length of $2.2363(13) \AA$ is only slightly elongated compared to that found in the anionic variant 2 (2.211(3) $\AA$ ).

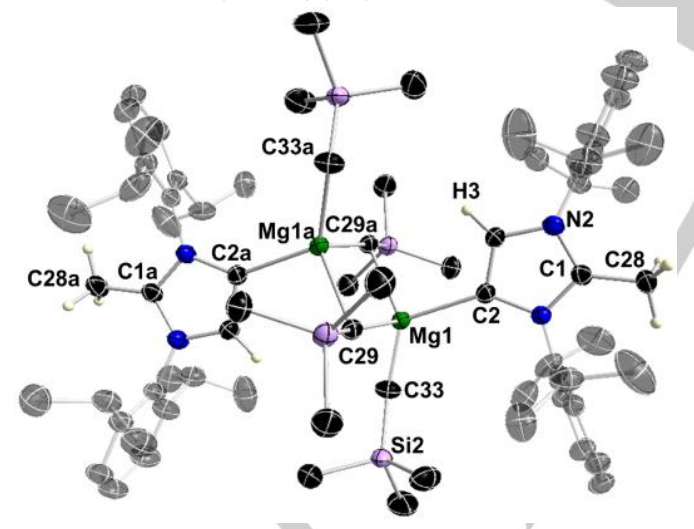

Figure 4. Molecular structure of $\mathbf{3}$ with displacement ellipsoids drawn at the $50 \%$ probability level. Hydrogen atoms except those on imidazole scaffold and newly installed methyl group have been omitted for clarity. Symmetry operator: $-x+2,-y+2,-z$.

The dimeric structure of $\mathbf{3}$ contrasts with that reported by Robertson and Mulvey for the normal IPr adduct of $\mathrm{MgR}_{2},{ }^{[11]}$ which is restricted to a monomeric architecture with a three- coordinate $\mathrm{Mg}$ center, exhibiting a $\mathrm{Mg}-\mathrm{C}_{\text {carbene }}$ bond distance of $2.267(3) \AA$. This different aggregation can be attributed to reduced steric demands of the aNHC ligand.

Reflecting the formation of a neutral aNHC complex, the ${ }^{13} \mathrm{C}$ NMR spectrum of 3 in $\mathrm{C}_{6} \mathrm{D}_{6}$ shows a resonance at $143.5 \mathrm{ppm}$ for the $\mathrm{C} 4$ attached to $\mathrm{Mg}$ ( vs $163.9 \mathrm{ppm}$ in anionic NHC complex 2) whereas the $\mathrm{C}$-atom that has undergone methylation (originally C2 carbenic position in 2 resonates significantly upfield at 165.1 ppm in comparison to that observed for 2 (at 200.2 ppm). ${ }^{[35]}$ During the spectroscopic characterization of $\mathbf{3}$ it became apparent that this complex was not stable in deuterated THF, with rapid conversion of the alPrMe ligand to a new species, which displayed two distinct new resonances in the ${ }^{1} \mathrm{H}$ NMR spectrum at 2.40 and $5.85 \mathrm{ppm}$ and a symmetrical imidazole ring. Comparison of ${ }^{1} \mathrm{H}$ and ${ }^{13} \mathrm{C}$ NMR data was consistent with the formation of olefinic $\mathrm{NHC}$ IPr= $\mathrm{CH}_{2}$ previously reported by Rivard ${ }^{[36]}$ and Robinson. ${ }^{[37]}$ In contrast, this decomposition pathway was extremely slow when $\mathbf{3}$ was dissolved in noncoordinating solvents such as hexane, toluene and benzene. ${ }^{[38]}$ Formation of 4 can be rationalized assuming that in THF solutions, 3 undergoes de-cocomplexation with alPrMe being replaced by the Lewis donor solvent [(i) in Scheme 3].

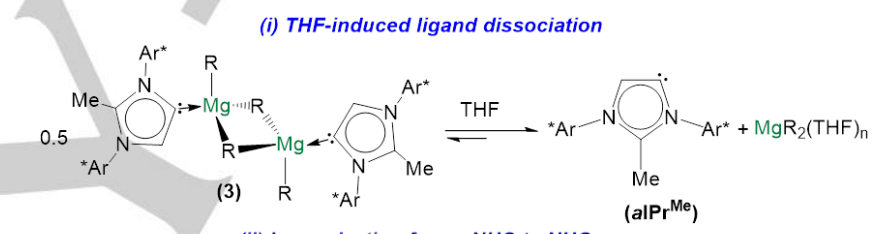

(ii) Isomerization from aNHC to $\mathrm{NHO}$

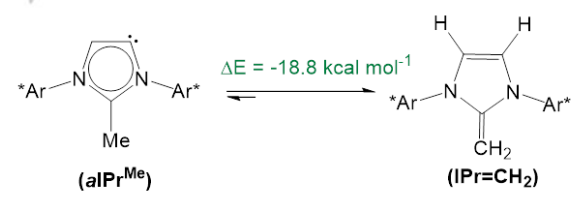

(iii) Deuterium labelling using $\mathrm{CD}_{3} \mathrm{OTf}$

$$
\text { (2) }
$$

Scheme 3. Decomposition pathway of $\mathbf{3}$ in THF: i) THF-induced ligand dissociation; ii) isomerization of aNHC to $\mathrm{NHO}$; iii) deuterium labelling experiment.

The preferred coordination of THF over an NHC ligand to the $\mathrm{MgR}_{2}$ fragment has already been observed for $\mathbf{I P r}^{\mathrm{TMS}}$ (vide supra). Related to the strength of the $\mathrm{Mg}-\mathrm{C}_{\mathrm{NHC}}$ bonds in $\mathrm{Mg}$ complexes, Mulvey and Robertson have also noted that in certain cases, such as for $\mathrm{IPr} \cdot \mathrm{Mg}^{n} \mathrm{Bu}(\mathrm{TMP})$, the steric clash induces the dissociation of the $\mathrm{NHC}$ adduct in its constituting reagents even in non-coordinating $\mathrm{C}_{6} \mathrm{D}_{6}$ solutions. ${ }^{[10]}$ As a noncoordinated entity, alPrMe can be expected to be highly unstable and "tautomerises" to olefinic carbene $\mathbf{I P r}=\mathrm{CH}_{2}$ [(ii) in Scheme 3]. Rivard has labelled complexes of this type $\mathrm{N}$-heterocyclic olefins (NHOs). ${ }^{[39]}$ DFT calculations showed that this isomerization from aNHC to $\mathrm{NHO}$ is actually energetically favoured by $18.8 \mathrm{kcalmol}^{-}$ 
1. Supporting this interpretation, deuterium labeling of the Me group attached at the $\mathrm{C} 2$ position of $\mathbf{3}$ (synthesized by reacting 2 with $\left[D_{3}\right]-$ MeOTf formed $\mathbf{I P r}^{\mathrm{D}}=\mathbf{C D}_{2}$ where deuterium have been incorporated at the $\mathrm{C} 4$ position of the imidazole ring and the methylene fragment [see (iii) in Scheme 3, Figure S7]. Building on our previous mechanistic studies on the isomerization of IPr to alPr in Ga complexes, ${ }^{[28]}$ and considering that $a \mathrm{NHCs}$ have been found to be stronger bases than their normal counterparts ${ }^{[7]}$ we can envisage that the formation of $\mathrm{IPr}=\mathrm{CH}_{2}$ occurs by the generation of free alPrMe that can intermolecularly deprotonate the Me group which binds to the $\mathrm{C} 2$ atom of another imidazole ring. Notably, highlighting again the similarities between 2 and Robinson's lithiated IPr complex, ${ }^{\left[{ }^{[0]}\right.}$ when the latter is reacted with methyl iodide, it affords $\mathbf{I P r}=\mathrm{CH}_{2}$ in almost quantitative yields. ${ }^{[37]}$ However, on this occasion the formation of an intermediate abnormal NHC complex (like 3) could not be detected. It should also be noted that contrasting with the lability of the alPrMe component in complex 3 in THF solution, complex 2 where $\left\{\mathrm{MgR}_{2}\right\}$ is attached to the $\mathrm{C} 4$ position of an anionic $\mathrm{NHC}$ is perfectly stable in this donor solvent and does not undergo any side reactions.

\section{Assessing Transmetallation behaviours towards Au complexes}

Our previous explorations of the reactivity of sodium zincates containing anionic NHCs have shown they can be excellent transfer agents to transition metal complexes, in particular gold systems, enabling the isolation of a novel complex where the anionic NHC connects two different Au centres (see complex I in Scheme 4) as the result of a dual transmetallation process. ${ }^{[26]}$

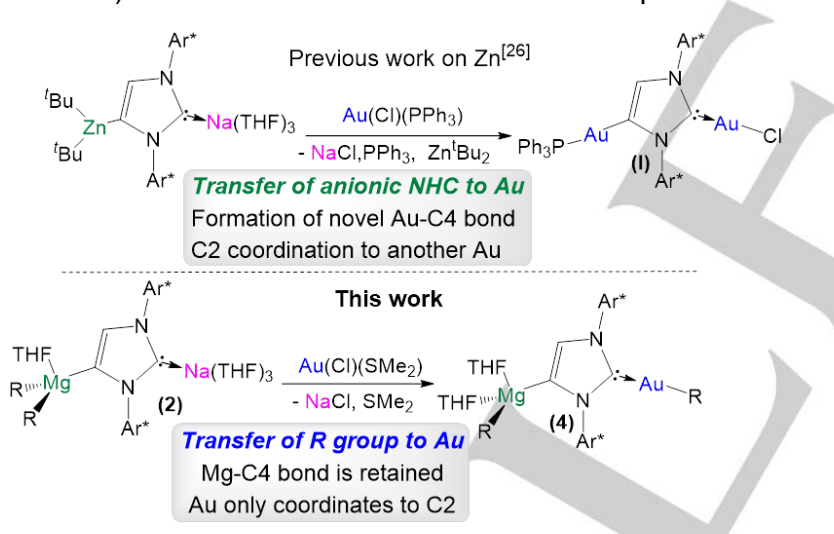

Scheme 4. Comparison of reactivity of anionic NHC-containing sodium zincate and sodium magnesiate reagents towards gold(I) compounds.

This complex is a rare example of an anionic NHC complex bridging between two different transition metal centres. ${ }^{[40]}$ Interestingly, previous work by Meyer has identified the formation of anionic NHC complexes between two Pd centres as a self-deactivation process in (allyl) PdNHC complexes. ${ }^{[40 c]}$ Since initial reactivity studies are consistent with a large polarization of the $\mathrm{Mg}-\mathrm{C} 4$ bond in 2, we next pondered if it could also undergo transmetallation reactions towards $\mathrm{Au}(\mathrm{I})$ complexes. Thus, sodium magnesiate 2 was reacted with an equimolar amount of $\left[\mathrm{Au}(\mathrm{Cl})\left(\mathrm{SMe}_{2}\right)\right]$ in toluene at $-70^{\circ} \mathrm{C}$ which afforded the novel mixed $\mathrm{Mg} / \mathrm{Au}$ bimetallic complex [RAu( $\mu$-IPr- $) \mathrm{MgR}(\mathrm{THF})_{2}$ ] (4) in $40 \%$ yield (Scheme 4 ).

X-ray crystallographic studies of 4 confirmed that transmetallation had indeed taken place. However, instead of transferring the anionic IPr ligand to Au, 2 selectively transfers one of its anionic alkyl $R$ groups, with the subsequent precipitation of $\mathrm{NaCl}$ (Figure 5). This creates a coordination vacancy in the $\mathrm{C} 2$ position of the anionic carbene (originally bound to $\mathrm{Na}$ ) which can in turn replace the labile $\mathrm{SMe}_{2}$ ligand on $\mathrm{Au}$ to furnish 4 (Scheme 4). This reactivity departs from that previously discussed for $\mathrm{Na} / \mathrm{Zn}$ systems where the alkyl groups remain coordinated to $\mathrm{Zn}$ and are not involved in the transmetallation process. ${ }^{[26]}$ It also differs from Tamm's studies on the reactivity of $\left[\left(\mathrm{PPh}_{3}\right) \mathrm{AuCl}\right]$ with an anionic lithium carbene containing a borate moiety on its imidazole backbone. ${ }^{[41]}$ In this case a neutral mononuclear gold species is obtained, resulting from the single exchange of the $\mathrm{C} 2$ position of $\mathrm{Li}$ (which is eliminated as $\mathrm{LiCl})$ and the $\left\{\mathrm{Au}\left(\mathrm{PPh}_{3}\right)\right\}^{+}$cation, keeping the borate part of the $\mathrm{NHC}$ intact.

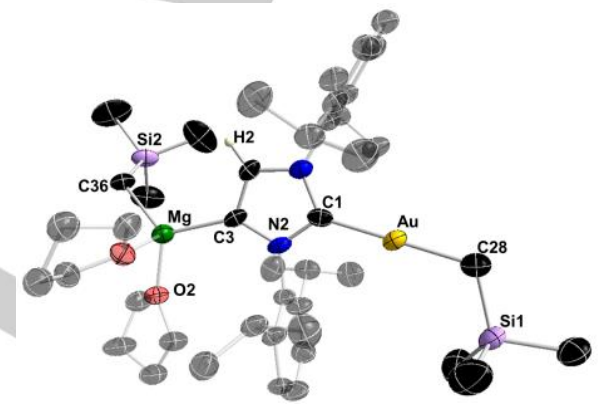

Figure 5. Molecular structure of $\mathbf{4}$ with displacement ellipsoids drawn at the $50 \%$ probability level. Hydrogen atoms have been omitted for clarity.

A close inspection on the geometrical parameters of 4 revealed that the $\mathrm{Au}-\mathrm{C}_{\mathrm{NHC}}$ bond distance [i.e Au-C1, 2.022(10) $\AA$ ] is notably elongated when compared to those in other $\mathrm{Au}(\mathrm{I})$ complexes containing neutral $\mathrm{NHC}$ ligands such as IPrAuCl $[1.942(3) \AA]^{[42]}$ or that one found for digold complex I $^{[26]}$ (Scheme 4) which also contains an anionic IPr ligand coordinated to one Au via its C2 position [1.975(5) $\AA$ ]. However, it compares well with those reported for $\mathrm{Au}(\mathrm{I})$ complexes which contain an anionic $\mathrm{NHC}$ with a weakly coordinating borate at the $\mathrm{C} 4$ position such as in $\left[\left(\mathrm{PPh}_{3}\right) \mathrm{Au}\left(\mu-\mathrm{IPr}-\mathrm{B}\left(\mathrm{C}_{6} \mathrm{~F}_{5}\right)_{3}\right\}\right]\left[\mathrm{Au}-\mathrm{C}_{\mathrm{NHC}}\right.$ bond distances of 2.037(2) $\AA] .{ }^{[41]}$ For this family of compounds, the negative charge on the anionic NHC ligand is presumed to be located on the C4 (abnormal) position bonded to the borane moiety. In addition, comparing the $\mathrm{Mg}-\mathrm{C}$ bonds in $\mathbf{4}$ with those observed in 2, both $\mathrm{Mg}-\mathrm{C}_{\text {alkyl }}$ and $\mathrm{Mg}-\mathrm{C}_{\mathrm{NHC}}$ are notably shorter [2.127(11) and $2.143(10) \AA$ in 4 vs $2.211(3)$ and $2.182 \AA$ in 2 respectively], which is consistent with the magnesiate constitution of 2 as opposed to 4 which can best be envisaged as a coordination adduct between $\left\{(\mathrm{THF})_{2} \mathrm{RMgIPr}-\right\}$ and AuR. Regarding its spectroscopic characterization using ${ }^{1} \mathrm{H}$ and ${ }^{13} \mathrm{C}$ multinuclear NMR spectroscopy, two informative resonances in the ${ }^{13} \mathrm{C} N M R$ spectrum of 4 in $d_{8}$-THF were observed at 155.6 and $199.4 \mathrm{ppm}$ which can be assigned to the $\mathrm{C} 4-\mathrm{Mg}$ and $\mathrm{C} 2-\mathrm{Au}$ fragments respectively. Reflecting the changes in the $\mathrm{Mg}$ coordination 
sphere, the C4-Mg resonance in $\mathbf{4}$ is significantly shifted upfield compared to the same resonance in the related sodium magnesiate 2 observed at 163.9 ppm; whereas the one for the carbenic $\mathrm{C}$ appears at a similar chemical shift to those previously described in the literature for normal $\mathrm{NHC}-\mathrm{Au}$ complexes in deuterated THF solution. ${ }^{[43]}$ Building on the studies on electrophilic interception of $\mathbf{2}$ to render $\mathrm{aNHC} \mathrm{Mg}$ complex $\mathbf{3}$, we next probed the reactivity of 4 towards MeOTf. However, despite several attempts the reaction proved to be unselective yielding in solution a complex mixture of species that could not be identified by ${ }^{1} \mathrm{H}$ NMR spectroscopy. As an alternative method, we next pondered whether 3 could transfer its aNHC ligand to $\mathrm{Au}$. Thus, $\left[\mathrm{Au}(\mathrm{Cl})\left(\mathrm{PPh}_{3}\right)\right]$ was added to an in situ prepared solution of $\mathbf{3}$ in toluene, affording gold complex [alPrMe AuR] (5) in $56 \%$ yield (Scheme 5 )

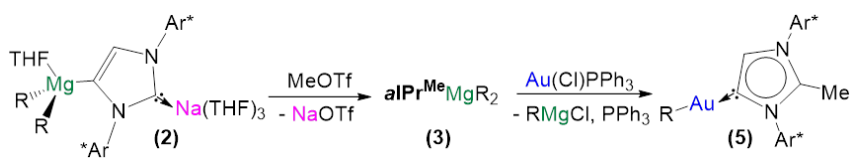

Scheme 5. Stepwise synthesis of $\mathbf{5}$ from sodium magnesiate 2

Interestingly, the neutral aNHC complex 3 induces a double transmetallation reaction, with carbene alPr ${ }^{\mathrm{Me}}$ replacing $\mathrm{PPh}_{3}$ as a neutral donor but also with the substitution of $\mathrm{Cl}$ by a monosilyl group. X-ray crystallographic studies established the molecular structure of 5 (Figure 6), with $\mathrm{Au}$ in an almost linear geometry $\left(\mathrm{C}_{\text {alkyl }}-\mathrm{Au}-\mathrm{C}_{\mathrm{NHC}}\right.$ bond angle, $\left.178.74(16)^{\circ}\right]$. The Au- $\mathrm{C}_{\text {carbene }}$ bond length of 2.036(3) $\AA$ falls within the range observed previously for other aNHC-Au complexes ${ }^{[7,43]}$ and it is slightly shorter than the Au- $\mathrm{C}_{\text {akkyl }}$ bond length $[2.054(3) \AA]$.
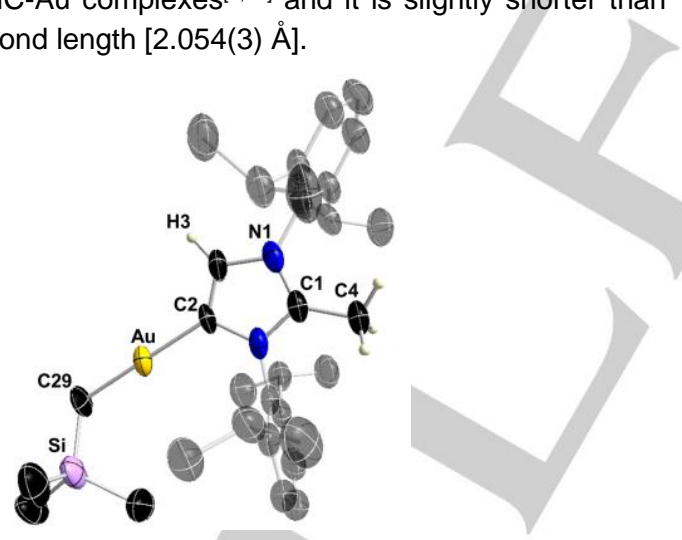

Figure 6. Molecular structure of $\mathbf{5}$ with displacement ellipsoids drawn at the $50 \%$ probability level. Hydrogen atoms except those on newly installed methyl group have been omitted for clarity.

In addition, the ${ }^{13} \mathrm{C}$ NMR spectrum of $\mathbf{5}$ displayed a diagnostic signal at $141.7 \mathrm{ppm}$ for the carbenic position which is within the range of chemical shifts previously reported for $\mathrm{Au}$ aNHC complexes. ${ }^{[44]}$

Isolation of $\mathbf{5}$ has disclosed a new method to access aNHC Au complexes which employs an anionic NHC as the source of the carbene ligand. Previous examples described in the literature involved the use of 2,4-functionalized imidazolium salts, which can be subsequently deprotonated by a Group 1 metal base or $\mathrm{Ag}_{2} \mathrm{O}$ in the presence of a $\mathrm{Au}$ precursor. ${ }^{[7,45,46]}$ In addition, Hashmi has reported a versatile synthesis of a range of abnormal NHC-Gold(I) complexes prepared by [3+2] cycloaddition of azomethine ylides to isonitrile gold(I) complexes which affords air- and light-stable crystalline solids. ${ }^{[47]}$

\section{Conclusions}

Exploring bimetallic approaches for metallation of IPr, two novel NHC-stabilized sodium magnesiates have been structurally characterized: higher order tetraorganomagnesiate $\left[\mathrm{IPr}_{2} \mathrm{Na}_{2} \mathrm{MgR}_{4}\right](\mathbf{1})\left(\mathrm{R}=\mathrm{CH}_{2} \mathrm{SiMe}_{3}\right)$ arising from an $\mathrm{NHC}$-induced redistribution process; and $\left[(\mathrm{THF})_{3} \mathrm{Na}(\mu-\mathrm{IPr}) \mathrm{MgR}_{2}(\mathrm{THF})\right]$ (2), which contains an anionic NHC. Contrasting with our previous work on TMP-based sodium magnesiates, here the lower order variant $\mathrm{NaMgR}_{3}$ is not powerful enough to deprotonate the imidazole backbone of IPr. However, highlighting the potential of sequential reactivity in mixed-metal chemistry, by treating IPr with $\mathrm{NaR}$ followed by addition of $\mathrm{MgR}_{2}$ complex 2 is obtained, where a $\left\{\mathrm{MgR}_{2}(\mathrm{THF})\right\}$ fragment coordinates to the $\mathrm{C} 4$ position of the anionic NHC, while the $\mathrm{C} 2$ site is occupied by a $\left\{\mathrm{Na}(\mathrm{THF})_{3}\right\}^{+}$ cation.

Studies on the reactivity of $\mathbf{2}$ with electrophiles showed that while $\mathrm{Me}_{3} \mathrm{SiCl}$ reacts preferentially with the $\mathrm{C} 4$ position of the anionic carbene to give normal IPr ${ }^{\mathrm{TMS}}$ which contains a $\mathrm{SiMe}_{3}$ substituent at its imidazole backbone, MeOTf induces selective C2-methylation of anionic IPr in 2 to form novel abnormal $\mathrm{Mg}$ aNHC complex $\left[\left\{\right.\right.$ alPr $^{\left.\left.\mathrm{Me} M g R_{2}\right\}_{2}\right]} \quad$ (3), which was crystallographically characterised. Interestingly these studies also revealed the preference of $\mathrm{MgR}_{2}$ to coordinate to the hard Lewis donor solvent THF over softer, neutral normal and abnormal NHCs. In the case of $\mathbf{3}$, this preference translates in the dissociation of the carbene adduct, releasing $\mathrm{IPr}^{\mathrm{Me}}$ which converts into the olefinic $\mathrm{NHO}$ compound $\mathrm{IPr}=\mathrm{CH}_{2}$. Advancing the understanding on the formation of olefinic carbenes, this work demonstrates the involvement of an aNHC metal complex as a key intermediate.

In addition, by assessing the ability of $\mathbf{2}$ and $\mathbf{3}$ to transfer their anionic and abnormal NHC ligands respectively to gold(I) complexes we have isolated and structurally characterised complexes $\mathbf{4}$ and $\mathbf{5}$ which in both cases contain an alkyl $\mathrm{CH}_{2} \mathrm{SiMe}_{3}$ bound to $\mathrm{Au}$. Showing a remarkably distinct reactivity, 2 only transfers one of its alkyl groups from $\mathrm{Mg}$ to $\left[\mathrm{Au}\left(\mathrm{SMe}_{2}\right) \mathrm{Cl}\right.$, with the retention of the Mg-C4 bond to anionic IPr. This ligand transfer occurs with the concomitant precipitation of $\mathrm{NaCl}$, which in creating a coordination vacancy at the normal $\mathrm{C} 2$ position of the anionic $\mathrm{NHC}$, allows its filling by the newly generated $\left\{\mathrm{Au}\left(\mathrm{CH}_{2} \mathrm{SiMe}_{3}\right)\right\}$ fragment. Contrastingly 3 transfers both alkyl and $\mathrm{aNHC}$ ligands to $\left[\mathrm{Au}\left(\mathrm{PPh}_{3}\right) \mathrm{Cl}\right.$ ] furnishing 6 and unveiling a new synthetic approach to access abnormal Au NHC complexes. Collectively this work not only advances the synthesis of anionic and abnormal NHC Mg complexes, but also provides novel reactivity insights on how these compounds can be exploited in transmetallation reactions to access unique $\mathrm{NHC}$ complexes of transition metals, as well as revealing key aspects of their 
stability towards dissociation in donor solvents and the role of $\mathbf{3}$ in forming $\mathrm{NHOs.}$

\section{Experimental Section}

All reactions were performed under a protective argon atmosphere using standard Schlenk techniques. $n$-Hexane, THF and toluene were dried by heating to reflux over sodium benzophenone ketyl and distilled under nitrogen prior to use. $\mathrm{Na}\left(\mathrm{CH}_{2} \mathrm{SiMe}_{3}\right),{ }^{[48]}\left[\mathrm{AuCl}\left(\mathrm{PPh}_{3}\right)\right],{ }^{\left[{ }^{[49]}\right.} \mathbf{I P r},{ }^{[50]}$ and $\left[\mathrm{NaMg}\left(\mathrm{CH}_{2} \mathrm{SiMe}_{3}\right)_{3}\right]^{[16]}$ were synthesized as described in the literature. $\left[\mathrm{AuCl}\left(\mathrm{SMe}_{2}\right)\right]$ and TfOMe were purchased from Sigma Aldrich Chemicals, and used as received. $\mathrm{Mg}\left(\mathrm{CH}_{2} \mathrm{SiMe}_{3}\right)_{2}$ was prepared from the Grignard reagent $\left(\mathrm{Me}_{3} \mathrm{SiCH}_{2}\right) \mathrm{MgCl}$ by manipulation of the Schlenk equilibrium via the dioxane precipitation method. The resultant off-white solid was purified via sublimation at $175^{\circ} \mathrm{C}\left(10^{-2}\right.$ Torr $)$ to furnish pure $\mathrm{Mg}\left(\mathrm{CH}_{2} \mathrm{SiMe}_{3}\right)_{2}$. NMR spectra were recorded on a Bruker DPX $400 \mathrm{MHz}$ spectrometer, operating at $400.13 \mathrm{MHz}$ for ${ }^{1} \mathrm{H}, 155.50 \mathrm{MHz}$ for ${ }^{7} \mathrm{Li}$, and 100.62 $\mathrm{MHz}$ for ${ }^{13} \mathrm{C}\left\{{ }^{1} \mathrm{H}\right\}$. Elemental analyses were obtained using a Perkin-Elmer 2400 elemental analyzer. Crystallographic data were measured at $123(2) \mathrm{K}$ on Oxford Diffraction diffractometers ${ }^{[51]}$ with Mo $\mathrm{Ka}(\lambda=0.71073 \AA)$ or $\mathrm{Cu} \mathrm{Ka}(\lambda=1.5418 \AA)$ radiation. Structures were refined to convergence on $F^{2}$ and against all independent reflections by the full-matrix least squares method using the SHELXL-97 program. ${ }^{[52]}$ Copies of NMR spectra of compounds 1-5 are included in the Supporting Information. CCDC 1838641-1838645 contain the supplementary crystallographic data of this paper. These data can be obtained free of charge from the Cambridge Crystallographic Data Centre via www.ccdc.cam.ac.uk/data request/cif.

Synthesis of $\left[\mathrm{IPr}_{2} \mathrm{Na}_{2} \mathrm{MgR}_{4}\right]$ (1) To a suspension of $\mathrm{NaCH}_{2} \mathrm{SiMe}_{3}(0.055$ $\mathrm{g}, 0.5 \mathrm{mmol})$ in hexane $(10 \mathrm{~mL}) \mathrm{Mg}\left(\mathrm{CH}_{2} \mathrm{SiMe}_{3}\right)_{2}(0.1 \mathrm{~g}, 0.5 \mathrm{mmol})$ was added and the suspension stirred for 1 hour. Benzene $(15 \mathrm{~mL})$ was then added giving an almost clear solution followed by $\operatorname{IPr}(0.20 \mathrm{~g}, 0.5 \mathrm{mmol})$ giving a straw solution. All the volatiles were removed under vacuo and hexane $(5 \mathrm{~mL})$ was added which gave a clear solution on gentle heating. Storage in the freezer $\left(-28{ }^{\circ} \mathrm{C}\right)$ overnight produced a crop of crystals which was isolated $(0.04 \mathrm{~g}, 13 \%) .{ }^{1} \mathrm{H}$ NMR $\left(400.13 \mathrm{MHz}, 298 \mathrm{~K}, \mathrm{C}_{6} \mathrm{D}_{6}\right) \delta$ (ppm) -1.91 (s, 8H, $\left.\mathrm{CH}_{2} \mathrm{SiMe}_{3}\right), 0.20\left(\mathrm{~s}, 36 \mathrm{H}, \mathrm{CH}_{2} \mathrm{SiMe}_{3}\right), 1.02(24 \mathrm{H}, \mathrm{d}, \mathrm{J}$ $\left.=6.8 \mathrm{~Hz}, \mathrm{CH}\left(\mathrm{CH}_{3}\right)_{2}\right), 1.26\left(24 \mathrm{H}, \mathrm{d}, \mathrm{J}=6.8 \mathrm{~Hz}, \mathrm{CH}\left(\mathrm{CH}_{3}\right)_{2}\right), 2.58(8 \mathrm{H}, \mathrm{m}$, $\left.\mathrm{CH}\left(\mathrm{CH}_{3}\right)_{2}\right), 6.41(4 \mathrm{H}, \mathrm{s}, \mathrm{NCHCHN}), 7.10(8 \mathrm{H}, \mathrm{d}, \mathrm{J}=7.8 \mathrm{~Hz}, \mathrm{Ar}-H), 7.27$ $(4 \mathrm{H}, \mathrm{t}, \mathrm{J}=7.8 \mathrm{~Hz}, \mathrm{Ar}-\mathrm{H}) .{ }^{13} \mathrm{C}\left\{{ }^{1} \mathrm{H}\right\} \mathrm{NMR}\left(100.62 \mathrm{MHz}, 298 \mathrm{~K}, \mathrm{C}_{6} \mathrm{D}_{6}\right) \delta$ (ppm) -3.0 ( $\left.\mathrm{CH}_{2} \mathrm{SiMe}_{3}\right), \quad 4.8 \quad\left(\mathrm{CH}_{2} \mathrm{SiMe}\right), \quad 24.3 \quad\left(\mathrm{CH}\left(\mathrm{CH}_{3}\right)_{2}\right), \quad 24.5$ $\left(\mathrm{CH}\left(\mathrm{CH}_{3}\right)_{2}\right), 28.6\left(\mathrm{CH}\left(\mathrm{CH}_{3}\right)_{2}\right), 122.7(\mathrm{NCHCHN}), 124.4(\mathrm{ArCH}), 130.5$ $(\mathrm{ArCH}), 136.3(\mathrm{ArC}), 145.5(\operatorname{ArC}), 202.9(\mathrm{NCN})$. Despite several attempts due to the extremely air sensitive nature of this compound, no satisfactory elemental analysis could be obtained.

Synthesis of [(THF) ${ }_{3} \mathrm{Na}(\boldsymbol{\mu}-\mathrm{IPr}) \mathrm{MgR}_{\mathbf{2}}$ (THF)] (2) To a suspension of IPr $(1.40 \mathrm{~g}, 3.6 \mathrm{mmol})$ in hexane $(40 \mathrm{~mL})$ was added $\mathrm{NaR}(0.44 \mathrm{~g}, 4 \mathrm{mmol})$ and stirred for 1 hour, after which $\mathrm{MgR}_{2}(0.79 \mathrm{~g}, 4 \mathrm{mmol})$ was added and the suspension stirred overnight. THF was added dropwise $(11 \mathrm{~mL})$ and the clear solution transferred to the freezer which overnight deposited a crop of colourless crystals $(1.86 \mathrm{~g}, 58 \%) .{ }^{1} \mathrm{H}$ NMR $(400.03 \mathrm{MHz}, 298 \mathrm{~K}$, $\mathrm{d}_{8}$-THF) $\delta$ (ppm) -2.11 (s, 4H, $\left.\mathrm{CH}_{2} \mathrm{SiMe}_{3}\right), 0.23$ (s, 18H, $\mathrm{CH}_{2} \mathrm{SiMe}$ ), 1.10 $\left(\mathrm{d}, \mathrm{J}=6.8 \mathrm{~Hz}, 6 \mathrm{H}, \mathrm{CH}\left(\mathrm{CH}_{3}\right)_{2}\right), 1.13\left(\mathrm{~d}, \mathrm{~J}=6.8 \mathrm{~Hz}, 6 \mathrm{H}, \mathrm{CH}\left(\mathrm{CH}_{3}\right)_{2}\right), 1.17$ (d, $\left.\mathrm{J}=6.8 \mathrm{~Hz}, 6 \mathrm{H}, \mathrm{CH}\left(\mathrm{CH}_{3}\right)_{2}\right), 1.24\left(\mathrm{~d}, \mathrm{~J}=6.8 \mathrm{~Hz}, 6 \mathrm{H}, \mathrm{CH}\left(\mathrm{CH}_{3}\right)_{2}\right), 1.78(\mathrm{~m}$, $12 \mathrm{H}, \mathrm{THF}), 2.96\left(\mathrm{~m}, 2 \mathrm{H}, \mathrm{CH}\left(\mathrm{CH}_{3}\right)_{2}\right), 3.09\left(\mathrm{~m}, 2 \mathrm{H}, \mathrm{CH}\left(\mathrm{CH}_{3}\right)_{2}\right), 3.62(\mathrm{~m}$, $12 \mathrm{H}, \mathrm{THF}), 6.56$ (s, 1H, NCHCN), 7.10-7.23 (overlapping $\mathrm{m}, 6 \mathrm{H}, \mathrm{ArCH}$ ), ${ }^{13} \mathrm{C}\left\{{ }^{1} \mathrm{H}\right\}$ NMR $\left(100.62 \mathrm{MHz}, 298 \mathrm{~K}, \mathrm{~d}_{8}-\mathrm{THF}\right) \delta(\mathrm{ppm})-5.9\left(\mathrm{CH}_{2} \mathrm{SiMe}_{3}\right), 5.2$ $\left(\mathrm{CH}_{2} \mathrm{SiMe} 3\right), 24.1\left(\mathrm{CH}\left(\mathrm{CH}_{3}\right)_{2}\right), 24.9\left(\mathrm{CH}\left(\mathrm{CH}_{3}\right)_{2}\right), 25.3\left(\mathrm{CH}\left(\mathrm{CH}_{3}\right)_{2}\right), 25.7$ $\left(\mathrm{CH}\left(\mathrm{CH}_{3}\right)_{2}\right), 26.4$ (THF), $28.6\left(\mathrm{CH}\left(\mathrm{CH}_{3}\right)_{2}\right), 68.2(\mathrm{THF}), 123.5(\mathrm{ArCH})$, 123.8 ( $\mathrm{ArCH}), 127.3(\mathrm{ArCH}), 128.4(\mathrm{ArCH}), 131.2(\mathrm{NCHCN}), 141.1(\mathrm{ArC})$,
$145.7(\operatorname{ArC}), 146.9(\operatorname{ArC}), 147.3(\operatorname{ArC}), 163.9(\mathrm{NCHCN}), 200.2(\mathrm{NCN})$ Anal Calcd for $\mathrm{C}_{51} \mathrm{H}_{89} \mathrm{MgN}_{2} \mathrm{NaO}_{4} \mathrm{Si}_{2}: \mathrm{C}, 68.23 ; \mathrm{H}, 9.99 ., \mathrm{N}$ 3.12. Found: $\mathrm{C}$ $67.90, \mathrm{H}, 10.03, \mathrm{~N} 3.56$.

Synthesis of [\{alPrMe $\left.\mathrm{MgR}_{2}\right\}_{2}$ ] (3) MeOTf $(0.07 \mathrm{~g}, 0.45 \mathrm{mmol})$ dissolved in $5 \mathrm{~mL}$ of toluene was added to a toluene $(30 \mathrm{~mL})$ solution of compound 2 at $-70^{\circ} \mathrm{C}$. The pale yellow solution was stirred for 30 min allowing reaching room temperature, and the resulting orange suspension was filtered. Toluene was removed under vacuum affording red oil, to which hexane $(2 \mathrm{~mL})$ was added precipitating a white solid. Finally, compound $3(0.08 \mathrm{~g}, 30 \%)$ was isolated by filtration and washing with hexane $(3 \times 2$ $\mathrm{mL}$ ) at $0{ }^{\circ} \mathrm{C} .{ }^{1} \mathrm{H} \mathrm{NMR}\left(400 \mathrm{MHz}, \mathrm{C}_{6} \mathrm{D}_{6}\right): \delta-1.24\left(\mathrm{~s}, 4 \mathrm{H}, \mathrm{CH}_{2} \mathrm{SiMe}_{3}\right), 0.36$ (s, $18 \mathrm{H}, \mathrm{CH}_{2} \mathrm{Si}_{\mathrm{Me}}$ ), 0.89 (d, J = $\left.6.8 \mathrm{~Hz}, 6 \mathrm{H}, \mathrm{CH}\left(\mathrm{CH}_{3}\right)_{2}\right), 0.92(\mathrm{~d}, \mathrm{~J}=6.8 \mathrm{~Hz}$ $\left.6 \mathrm{H}, \mathrm{CH}\left(\mathrm{CH}_{3}\right)_{2}\right), 1.05\left(\mathrm{~d}, \mathrm{~J}=6.8 \mathrm{~Hz}, 6 \mathrm{H}, \mathrm{CH}\left(\mathrm{CH}_{3}\right)_{2}\right), 1.34(\mathrm{~d}, \mathrm{~J}=6.8 \mathrm{~Hz}$, $\left.\left.6 \mathrm{H}, \mathrm{CH}\left(\mathrm{CH}_{3}\right)_{2}\right) 1.37(\mathrm{~s}, 3 \mathrm{H}, \mathrm{NCCH})_{3}\right), 2.32\left(\mathrm{~m}, 2 \mathrm{H}, \mathrm{CH}\left(\mathrm{CH}_{3}\right)_{2}\right), 2.53(\mathrm{~m}$ $\left.2 \mathrm{H}, \mathrm{CH}\left(\mathrm{CH}_{3}\right)_{2}\right), 6.93(\mathrm{~s}, 1 \mathrm{H}, \mathrm{NCHCN}), 6.96(\mathrm{~d}, \mathrm{~J}=8 \mathrm{~Hz}, 2 \mathrm{H}, \mathrm{Ar}-\mathrm{H}), 7.07$ $(\mathrm{d}, \mathrm{J}=8 \mathrm{~Hz}, 2 \mathrm{H}, \mathrm{Ar}-\mathrm{H}), 7.13(\mathrm{t}, \mathrm{J}=8 \mathrm{~Hz}, 1 \mathrm{H}, \mathrm{Ar}-\mathrm{H}), 7.21(\mathrm{t}, \mathrm{J}=8 \mathrm{~Hz}, 1 \mathrm{H}$, Ar-H). ${ }^{13} \mathrm{C}\left\{{ }^{1} \mathrm{H}\right\}$ NMR $\left(125 \mathrm{MHz}, \mathrm{C}_{6} \mathrm{D}_{6}\right): \delta-4.6\left(\mathrm{CH}_{2} \mathrm{SiMe}_{3}\right), 5.0\left(\mathrm{CH}_{2} \mathrm{SiMe}\right)$, $10.3\left(\mathrm{NCCH}_{3}\right), 23.4\left(\mathrm{CH}\left(\mathrm{CH}_{3}\right)_{2}\right), 23.8\left(\mathrm{CH}\left(\mathrm{CH}_{3}\right)_{2}\right), 24.5\left(\mathrm{CH}\left(\mathrm{CH}_{3}\right)_{2}\right), 24.6$ $\left(\mathrm{CH}\left(\mathrm{CH}_{3}\right)_{2}\right), 28.5\left(\mathrm{CH}\left(\mathrm{CH}_{3}\right)_{2}\right), 28.6\left(\mathrm{CH}\left(\mathrm{CH}_{3}\right)_{2}\right), 124.7(\mathrm{ArCH}), 130.6$ $(\mathrm{ArCH}), 131.1(\mathrm{ArCH}), 131.2(\mathrm{NCHCN}), 135.1(\mathrm{ArC}), 143.5(\mathrm{NCHCN})$, $144.8(\operatorname{ArC}), 145.6(\operatorname{ArC}), 165.1(\mathrm{NCN})$. Anal Calcd for $\mathrm{C}_{36} \mathrm{H}_{60} \mathrm{MgN}_{2} \mathrm{Si}_{2}: \mathrm{C}$, 71.90; H, 10.06., N 4.66. Found: C, 70.80, H, 9.97, N 5.13.

Following a similar procedure, to a toluene $(30 \mathrm{~mL})$ solution of compound 2 at $-70^{\circ} \mathrm{C}\left[\mathrm{D}_{3}\right] \mathrm{MeOTf}(0.07 \mathrm{~g}, 0.45 \mathrm{mmol})$ dissolved in $5 \mathrm{~mL}$ of toluene was added. The resulting solution was stirred while warming to room temperature. After 2 hours an aliquot of the toluene solution was analyzed by ${ }^{2} \mathrm{H}-\mathrm{NMR}$ spectroscopy (Figure S7).

Compound [\{RAu( $\left.\boldsymbol{\mu}-\mathrm{IPr}) \mathbf{M g R}(\mathrm{THF})_{2}\right]$ (4) To a toluene (10 $\left.\mathrm{mL}\right)$ solution of compound $2(0.45 \mathrm{~g}, 0.5 \mathrm{mmol})$ at $-70^{\circ} \mathrm{C}$ was added $\left(\mathrm{Me}_{2} \mathrm{~S}\right) \mathrm{AuCl}(0.15$ $\mathrm{g}, 0.5 \mathrm{mmol}$ ) followed by addition of $10 \mathrm{~mL}$ of THF. After 30 min stirring allowing reaching room temperature the solvent of the resulting light red solution was removed under vacuum and the residue was extracted with toluene $(2 \times 10 \mathrm{~mL})$. All the volatiles were removed in vacuo affording an oily residue which was dissolved in a mixture of THF $(2 \mathrm{~mL})$, hexane $(5$ $\mathrm{mL}$ ) and transferred to the freezer $\left(-30^{\circ} \mathrm{C}\right)$. A crop of colourless crystals was deposited overnight $(0.18 \mathrm{~g}, 40 \%) .{ }^{1} \mathrm{H}$ NMR $\left(400 \mathrm{MHz},\left[\mathrm{D}_{8}\right] \mathrm{THF}\right): \delta$ 1.85 (s, 2H, MgCH $\mathrm{SiMe}_{3}$ ), -0.68 (s, 2H, AuCH $\mathrm{SiMe}_{3}$ ), -0.47 (s, 9H, $\mathrm{MgCH}_{2} \mathrm{SiMe}_{3}$ ), $-0.14\left(\mathrm{~s}, 9 \mathrm{H}, \mathrm{AuCH}_{2} \mathrm{SiMe}_{3}\right), 1.16(\mathrm{~d}, \mathrm{~J}=6.8 \mathrm{~Hz}, 6 \mathrm{H}$, $\left.\mathrm{CH}\left(\mathrm{CH}_{3}\right)_{2}\right), 1.20\left(\mathrm{~d}, \mathrm{~J}=6.8 \mathrm{~Hz}, 6 \mathrm{H}, \mathrm{CH}\left(\mathrm{CH}_{3}\right)_{2}\right), 1.32(\mathrm{~d}, \mathrm{~J}=6.8 \mathrm{~Hz}, 6 \mathrm{H}$, $\left.\mathrm{CH}\left(\mathrm{CH}_{3}\right)_{2}\right), 1.37\left(\mathrm{~d}, \mathrm{~J}=6.8 \mathrm{~Hz}, 6 \mathrm{H}, \mathrm{CH}\left(\mathrm{CH}_{3}\right)_{2}\right), 1.77(\mathrm{~m}, 4 \mathrm{H}, \mathrm{THF}), 2.78$ $\left(\mathrm{m}, 2 \mathrm{H}, \mathrm{CH}\left(\mathrm{CH}_{3}\right)_{2}\right), 2.87\left(\mathrm{~m}, 2 \mathrm{H}, \mathrm{CH}\left(\mathrm{CH}_{3}\right)_{2}\right), 3.62(\mathrm{~m}, 4 \mathrm{H}, \mathrm{THF}), 6.70(\mathrm{~s}$, $1 \mathrm{H}, \mathrm{NCHCN}), 7.21\left(\mathrm{dd},{ }^{3} \mathrm{~J}=8 \mathrm{~Hz},{ }^{4} \mathrm{~J}=2.4 \mathrm{~Hz}, 4 \mathrm{H}, \mathrm{Ar}-\mathrm{H}\right), 7.32(\mathrm{~m}, 2 \mathrm{H}$, $\mathrm{Ar}-\mathrm{H}) .{ }^{13} \mathrm{C}\left\{{ }^{1} \mathrm{H}\right\}$ NMR $\left(125 \mathrm{MHz},\left[\mathrm{D}_{8}\right] \mathrm{THF}\right): \delta-.8 .8\left(\mathrm{MgCH}_{2} \mathrm{SiMe}_{3}\right), 3.7$ $\left.\left(\mathrm{MgCH}_{2} \mathrm{SiMe}_{3}\right), 4.4\left(\mathrm{AuCH}_{2} \mathrm{SiMe}\right)_{3}\right), 4.9\left(\mathrm{AuCH}_{2} \mathrm{SiMe}_{3}\right), 24.3\left(\mathrm{CH}\left(\mathrm{CH}_{3}\right)_{2}\right)$, $24.5\left(\mathrm{CH}\left(\mathrm{CH}_{3}\right)_{2}\right), 24.8\left(\mathrm{CH}\left(\mathrm{CH}_{3}\right)_{2}\right), 25.4\left(\mathrm{CH}\left(\mathrm{CH}_{3}\right)_{2}\right), 26.3$ (THF), 29.0 $\left(\mathrm{CH}\left(\mathrm{CH}_{3}\right)_{2}\right), 29.2\left(\mathrm{CH}\left(\mathrm{CH}_{3}\right)_{2}\right), 68.2(\mathrm{THF}), 123.9(\mathrm{ArCH}), 124.0(\mathrm{ArCH})$, $128.8(\mathrm{ArCH}), 129.3(\mathrm{ArCH}), 131.3(\mathrm{NCHCN}), 137.6(\operatorname{ArC}), 142.4(\mathrm{ArC})$, $146.7(\mathrm{ArC}), \quad 155.6(\mathrm{NCHCN}), \quad 199.5 \quad(\mathrm{NCN})$. Anal Calcd for $\mathrm{C}_{39} \mathrm{H}_{65} \mathrm{AuMgN}_{2} \mathrm{OSi}_{2}: \mathrm{C}, 54.76 ; \mathrm{H}, 7.66 ; \mathrm{N}, 3.27$. Found: $\mathrm{C}, 54.07, \mathrm{H}, 7.91$; $\mathrm{N}, 3.16$.

Synthesis of [alPrMeAuR] (5) MeOTf $(0.07 \mathrm{~g}, 0.45 \mathrm{mmol})$ dissolved in 5 $\mathrm{mL}$ of toluene was added to a toluene $(10 \mathrm{~mL})$ solution of compound 2 $(0.45 \mathrm{~g}, 0.5 \mathrm{mmol})$ at $-70^{\circ} \mathrm{C}$. The pale yellow solution was stirred for 10 $\mathrm{min}$ at that temperature, then $\left[\mathrm{AuCl}\left(\mathrm{PPh}_{3}\right)\right](0.24 \mathrm{~g}, 0.5 \mathrm{mmol})$ and $10 \mathrm{~mL}$ of THF were added. After $1 \mathrm{~h}$ stirring allowing the solution to warm to room temperature the solvent was removed under vacuum and the residue was extracted with toluene $(10 \mathrm{~mL})$. The solution was concentrated to $1 \mathrm{~mL}$ which was combined with $5 \mathrm{~mL}$ of hexane and transferred to the freezer $\left(-70{ }^{\circ} \mathrm{C}\right)$. A crop of colourless crystals was deposited overnight $(0.18 \mathrm{~g}, 56 \%) .{ }^{1} \mathrm{H}$ NMR $\left(400 \mathrm{MHz}, \mathrm{C}_{6} \mathrm{D}_{6}\right): \delta 0.33$ (s, $\left.9 \mathrm{H}, \mathrm{CH}_{2} \mathrm{SiMe}\right), 0.54\left(\mathrm{~s}, 2 \mathrm{H}, \mathrm{CH}_{2} \mathrm{SiMe}_{3}\right), 0.92(\mathrm{~d}, \mathrm{~J}=6.8 \mathrm{~Hz}, 6 \mathrm{H}$ 
$\left.\mathrm{CH}\left(\mathrm{CH}_{3}\right)_{2}\right), 0.93\left(\mathrm{~d}, \mathrm{~J}=6.8 \mathrm{~Hz}, 6 \mathrm{H}, \mathrm{CH}\left(\mathrm{CH}_{3}\right)_{2}\right), 1.04(\mathrm{~d}, \mathrm{~J}=6.8 \mathrm{~Hz}, 6 \mathrm{H}$ $\left.\mathrm{CH}\left(\mathrm{CH}_{3}\right)_{2}\right), 1.38(\mathrm{~s}, 3 \mathrm{H}, \mathrm{NCCH})_{3}, 1.60\left(\mathrm{~d}, \mathrm{~J}=6.8 \mathrm{~Hz}, 6 \mathrm{H}, \mathrm{CH}\left(\mathrm{CH}_{3}\right)_{2}\right), 2.35$ $\left(\mathrm{m}, 2 \mathrm{H}, \mathrm{CH}\left(\mathrm{CH}_{3}\right)_{2}\right), 2.68\left(\mathrm{~m}, 2 \mathrm{H}, \mathrm{CH}\left(\mathrm{CH}_{3}\right)_{2}\right), 6.54(\mathrm{~s}, 1 \mathrm{H}, \mathrm{NCHCN}), 6.92$ (d, J = $8 \mathrm{~Hz}, 2 \mathrm{H}, \mathrm{Ar}-\mathrm{H}), 7.15(\mathrm{t}, \mathrm{J}=8 \mathrm{~Hz}, 1 \mathrm{H}, \mathrm{Ar}-\mathrm{H}), 7.18(\mathrm{~m}, 2 \mathrm{H}, \mathrm{Ar}-\mathrm{H})$, 7.32 (t, J $=8 \mathrm{~Hz}, 1 \mathrm{H}$, Ar-H). ${ }^{13} \mathrm{C}\left\{{ }^{1} \mathrm{H}\right\}$ NMR $\left(125 \mathrm{MHz}, \mathrm{C}_{6} \mathrm{D}_{6}\right): \delta 4.4$ $\left(\mathrm{CH}_{2} \mathrm{SiMe}\right), \quad 6.5\left(\mathrm{CH}_{2} \mathrm{SiMe} 3\right), 10.5\left(\mathrm{NCCH}_{3}\right), 23.3\left(\mathrm{CH}\left(\mathrm{CH}_{3}\right)_{2}\right), 23.5$ $\left(\mathrm{CH}\left(\mathrm{CH}_{3}\right)_{2}\right), 24.3\left(\mathrm{CH}\left(\mathrm{CH}_{3}\right)_{2}\right), 24.7\left(\mathrm{CH}\left(\mathrm{CH}_{3}\right)_{2}\right), 28.6\left(\mathrm{CH}\left(\mathrm{CH}_{3}\right)_{2}\right), 29.0$ $\left(\mathrm{CH}\left(\mathrm{CH}_{3}\right)_{2}\right), 124.5(\mathrm{ArCH}), 124.6(\mathrm{ArCH}), 126.6(\mathrm{NCHCN}), 130.5(\mathrm{ArCH})$, $131.0(\mathrm{ArCH}), 131.3(\operatorname{ArC}), 135.3(\operatorname{ArC}), 141.7(\mathrm{NCHCN}), 145.1(\operatorname{ArC})$, 145.6 $(\mathrm{ArC}), 180.7(\mathrm{NCN})$. Anal Calcd for $\mathrm{C}_{32} \mathrm{H}_{49} \mathrm{AuN}_{2} \mathrm{Si}: \mathrm{C}, 55.96 \mathrm{H}$ 7.19; N, 4.08. Found: C, 55.99, H, 7.48; N, 3.82

\section{Acknowledgements}

Funding is acknowledged from the European Research Council (ERC) MIXMETAPPS-279590 FP7 project. We thank Professor Robert E Mulvey for his insightful comments and Mr Alexander Clunie for his assistance in the $\mathrm{CHN}$ analysis of highly air and moisture sensitive compounds.

Keywords: magnesiates $\cdot \mathrm{N}$-heterocyclic carbenes $\bullet$ metallation - cooperative effects $\cdot$ mixed metal

[1] a) W. A. Herrmann, M. Elison, J. Fischer, C. Köcher, G. R. J. Artus, Angew. Chem. Int. Ed. 1995, 34, 2371-2374; b) M. Scholl, S. Ding, C. W. Lee, R. H. Grubbs, Org. Lett. 1999, 1, 953-956; c) C. Valente, S Calimsiz, K. H. Hoi, D. Mallik, M. Sayah, M. G. Organ, Angew. Chem. 2012, 124, 3370-3388; Angew. Chem. Int. Ed. 2012, 51, 3314-3332; d) S. Diez-Gonzalez, N. Marion, S. P. Nolan, Chem. Rev. 2009, 109 3612-3676; e) N-Heterocyclic Carbenes in Transition Metal Catalysis and Organocatalysis (Ed.: C. S. J. Cazin), Springer, Netherlands, 2010; f) G. C. Vougioukalakis, R. H. Grubbs, Chem. Rev. 2010, 110, 1746 1787; g) G. C. Fortman, S. P. Nolan, Chem. Soc. Rev. 2011, 40, 51515169 .

[2] a) D. Holschumacher, T. Bannenberg, C. G. Hrib, P. G. Jones, M. Tamm, Angew. Chem. 2008, 120, 7538-7542; Angew. Chem. Int. Ed. 2008, 47, 7428-7432; b) S. Kronig, E. Theuergarten, D Holschumacher, T. Bannenberg, C. G. Daniliuc, P. G. Jones, M. Tamm Inorg. Chem. 2011, 50, 7344-7359; c) P. A. Chase, D. W. Stephan, Angew. Chem. 2008, 120, 7543-7547; Angew. Chem. Int. Ed. 2008, 47 7433 - 7437; d) M. A. Dureen, C. C. Brown, D. W. Stephan, Organometallics 2010, 29, 6594 - 6607; e) A. Jana, I. Objartel, H. W Roesky, D. Stalke, Inorg. Chem. 2009, 48, 7645-7649; f) B. Ines, S. Holle, R. Goddard, M. Alcarazo, Angew. Chem. 2010, 122, 8567-8569 Angew. Chem. Int. Ed. 2010, 49, 8389-8391.

[3] a) D. Enders, O. Niemeier, A. Henseler, Chem. Rev. 2007, 107, 56065655 ; b) P.-C. Chiang, J. W. Bode in N-Heterocyclic carbenes: From Laboratory Curiosities to Efficient Synthetic Tools (Ed.: S. DiezGonzalez), Royal Society of Chemistry, 2011, pp 399-435.

[4] a) Y. Wang, Y. Xie, P. Wei, R. B. King, H. F. Schaefer III, P. V. R. Schleyer,G. H. Robinson, Science, 2008, 321, 1069-1071; b) C. Jones, A. Sidiropoulos, N. Holzmann, G. Frenking, A. Stasch, Chem. Commun. 2012, 48, 9855-9857; c) Y. Wang, Y. Xie, P. Wei, R. B. King, H. F. Schafer III, P. v. R. Schleyer, G. H. Robinson, J. Am. Chem. Soc. 2008, 130, 14970-14971; d) H. Braunschweig, R. D. Dewhurst, K. Hammond, J. Mies, K. Radacki, A. Vargas, Science, 2012, 336, 1420-1422; e) Y. Wang, G. H. Robinson, Inorg. Chem. 2011, 50, 12326-12337.

[5] a) D. Bourissou, O. Guerret, F. P. Gabbai, G. Bertrand, Chem. Rev. 2010, 100, 39-91; b) M. N. Hopkinson, C. Richter, M. Schedler, F. Glorius, Nature, 510, 485-496.
[6] a) S. Gründemann, A. Kovacevic, M. Albrecht, J. W. Faller, R. H Crabtree, Chem. Commun. 2001, 2274; b) S. Gründemann, A. Kovacevic, M. Albrecht, J. W. Faller, R. H. Crabtree, J. Am. Chem. Soc. 2002, 124, 10473; c) P. L. Arnold, S. Pearson, Coord. Chem. Rev. 2007, 251, 596; d) R. H. Crabtree, Coord. Chem. Rev. 2013, 257, 755.

[7] E. Aldeco-Perez, A. J. Rosenthal, B. Donnadieu, P. Parameswaran, G. Frenking, G. Bertrand, Science, 2009, 326, 556.

[8] a) J. B. Waters, J. M. Goicoechea, Coord. Chem. Rev. 2015, 293-294 80-94; b) A. Nasr, A. Winkler, M. Tamm, Coord. Chem. Rev. 2016, 316, 68-124.

[9] Y. Wang, Y. Xie, M. Y. Abraham, P. Wei, H. F. Schaefer III, P. v. R Schleyer, G. H. Robinson, J. Am. Chem. Soc. 2010, 132, 14370-14372.

[10] A. R. Kennedy, R. E. Mulvey, S. D. Robertson, Dalton Trans. 2010, 39, 9091-9099.

[11] A. R. Kennedy, J. Klett, R. E. Mulvey, S. D. Robertson, Eur. J. Inorg. Chem. 2011, 4675-4679.

[12] A. J. Arduengo III, H. V. Rasika-Dias, R. Davidson, R. L. Harlow, J. Organomet. Chem. 1993, 462, 13-18.

[13] M. Arrowsmith, M. S. Hill, D. J. MacDougall, M. F. Mahon, Angew. Chem. 2009, 121, 4073-4076; Angew. Chem., Int. Ed. 2009, 48, 40134016

[14] A. J. Martínez-Martínez, M. Á. Fuentes, A. Hernán-Gómez, E. Hevia, A R. Kennedy, R. E. Mulvey, C. T. O'Hara, Angew. Chem. 2015, 127, 14281-14285; Angew. Chem., Int. Ed. 2015, 54, 14075-14079.

[15] M. S. Hill, G. Kociok-Köhn, D. J. MacDougall, Inorg. Chem. 2011, 50, 5234-5241.

[16] S. E. Baillie, W. Clegg, P. García-Alvarez, E. Hevia, A. R. Kennedy, J. Klett and L. Russo, Chem. Commum. 2011, 47, 388-390.

[17] A. Hernán-Gómez, T. D. Bradley, A. R. Kennedy, Z. Livingstone, S. D Robertson, E. Hevia, Chem. Commun. 2013, 49, 8659-8661.

[18] M. De Tullio, A. Hernán-Gómez, Z. Livingstone, W. Clegg, A. R Kennedy, R. W. Harrington, A. Antinolo, A. Martínez, F. CarrilloHermosilla, E. Hevia, Chem. Eur. J. 2016, 22, 17646-17656.

[19] ${ }^{1} \mathrm{H}$ NMR spectroscopic analysis of filtrate displayed a complex mixture of species which were not unambigously identified, however no species incorportaing deprotonated imidazole backbone as a product of metallation was detected. All our attempts, including the rational synthesis with correct stoichiometry, to increase the yield of $\mathbf{1}$ or to identify remaining species in solution were unsucesful.

[20] A. Hernán-Gómez, A. R. Kennedy, E. Hevia, Angew. Chem. 2017, 129, 6732-6735; Angew. Chem., Int. Ed., 2017, 56, 6632-6635.

[21] a) R. E. Mulvey, Chem. Commun. 2001, 1049-1056; b) D. R. Armstrong, E. Brammer, T. Cadenbach, E. Hevia, A. R. Kennedy, Organometallics 2013, 32, 480-489.

[22] L. C. H. Maddock, T. Cadenbach, A. R. Kennedy, I. Borilovic, G. Aromí, E. Hevia, Inorg. Chem. 2015, 54, 9201-9210.

[23] M. Uzelac, A. R. Kennedy, A. Hernán-Gómez, M. Á. Fuentes, E. Hevia, Z. Anorg. Allg. Chem. 2016, 642, 1241-1244.

[24] a) S. E. Baillie, W. Clegg, P. García-Alvarez, E. Hevia, A. R. Kennedy, J. Klett, L. Russo, Organometallics, 2012, 31, 5131-5142; b) S. E. Baillie T. D. Bluemke, W. Clegg, A. R. Kennedy, J. Klett, L. Russo, M. De Tullio, E. Hevia, Chem. Commun. 2014, 50, 12859-12862.

[25] M. Uzelac, E. Hevia, Chem. Commun. 2018, 54, 2455-2462.

[26] D. R. Armstrong, S. E. Baillie, V. L. Blair, N. G. Chabloz, J. Diez, J. Garcia-Alvarez, A. R. Kennedy, S. D. Robertson, E. Hevia, Chem. Sci. 2013, 4, 4259-4266

[27] R. S. Ghadwal, D. Rottschäfer, C. J. Schürmann, Z. Anorg. Allg. Chem. 2016, 642, 1236-1240.

[28] M. Uzelac, A. Hernán-Gómez, D. R. Armstrong, A. R. Kennedy, E. Hevia, Chem. Sci. 2015, 6, 5719-5728.

[29] B. M. Day, T. Pugh, D. Hendriks, C. F. Guerra, D. J. Evans, F. M. Bickelhaupt, R. A. Layfield, J. Am. Chem. Soc. 2013, 135, 13338-13341.

[30] A. L. Schmitt, G. Schnee, R. Welter and S. Dagorne, Chem. Commun. 2010, 46, 2480-2482. 
[31] Y. Wang, M. Y. Abraham, R. J. Gilliard Jr., P. Wei, J. C. Smith, G. H. Robinson, Organometallics 2012, 31, 791-793.

[32] M. Chen, Y. Wang, R. J. Gilliard Jr., P. Wei, N. A. Schwartz, G. H. Robinson, Dalton Trans. 2014, 43, 14211-14214

[33] Y. Wang, Y. Xie, M. Y. Abraham, R. J. Gilliard Jr., P. Wei, C. F. Campana, H. F. Schaefer III, P. v. R. Schleyer, G. H. Robinson, Angew. Chem. Int. Ed. 2012, 51, 10173-10176.

[34] D. Mendoza-Espinosa, B. Donnadieu, G. Bertrand, J. Am. Chem. Soc 2010, 132, 72647265.

[35] It should be noted that direct comparison of NMR spectra of $\mathbf{2}$ and $\mathbf{3}$ in the same solvent was not possible due to insolubility of 2 in $\mathrm{C}_{6} \mathrm{D}_{6}$ and decomposition of $\mathbf{3}$ in $\mathrm{d}_{8}$-THF.

[36] a) S. M. Ibrahim Al-Rafia, A. C. Malcolm, S. K. Liew, M. J. Ferguson, R. McDonald, E. Rivard, Chem. Commun. 2011, 47, 6987-6989; b) K Powers, C. Hering-Junghaus, R. McDonald, M. J. Ferguson, E. Rivard, Polyhedron 2016, 108, 8-14.

[37] Y. Wang, M. Y. Abraham, R. J. Gilliard Jr., D. R. Sexton, P. Wei, G. H. Robinson, Organometallics 2013, 32, 6639-6642.

[38] ${ }^{1} \mathrm{H}$ NMR monitoring of a solution of 3 in $\mathrm{C}_{6} \mathrm{D}_{6}$ showed slow decomposition to alPrMe, with $18 \%$ formation of IPr= $\mathbf{C H}_{2}$ after 8 days at room temperature.

[39] M. M. D. Roy, E. Rivard, Acc. Chem. Res. 2017, 50, 2017-2025.

[40] a) C. E. Ellul, M. F. Mahon, O. Saker, M. K. Whittlesey, Angew. Chem. Int. Ed. 2007, 46, 6343-6345; b) A. A. Danopoulos, D. Pugh, J. A Wright, Angew. Chem. Int. Ed. 2008, 47, 9765-9767; c) U. J. Scheele, S. Dechert, F. Meyer, Chem. Eur. J. 2008, 14, 5112-5115; d) M. R Crittall, C. E. Ellul, M. F. Mahon, O. Saker, M. K. Whittlesey, Dalton Trans. 2008, 4209-4211; e) A. Krüger, E. Kluser, H. Müller-Bunz, A Neels, M. Albrecht, Eur. J. Inorg. Chem. 2012, 1394-1402; f) M. J. Bitzer, A. Pöthig, C. Jandl, F. E. Kühn, W. Baratta, Dalton Trans. 2015, 44, 11686-11689; g) S. Gonell, M. Poyatos, E. Peris, Dalton Trans. 2016, 45, 5549-5556.

[41] S. Kronig, E. Theuergarten, C. G. Daniliuc, P. G. Jones, M. Tamm, Angew. Chem. Int. Ed. 2012, 51, 3240-3244.
[42] P. de Frémont, N. M. Scott, E. D. Stevens, S. P. Nolan, Organometallics 2005, 24, 2411-2418.

[43] C. Pranckevicius, L. Liu, G. Bertrand, D. W. Stephan, Angew. Chem. Int. Ed. 2016, 55, 5536-5540.

[44] Although direct comparison of NMR data for $\mathbf{5}$ with literature values is complicated by different solvent used, it is in agreement with the 143-64 ppm range reported. See references $7, \mathbf{4 5 d}, \mathbf{f}$ and $\mathbf{g}$

[45] a) G. Ung, D. Mendoza-Espinosa, G. Bertrand, Chem. Commun. 2012 48, 7088-7090; b) G. Ung, D. Mendoza-Espinosa, J. Bouffard, G. Bertrand, Angew. Chem. Int. Ed. 2011, 50, 4215-4218; c) D. MendozaEspinosa, G. Ung, B. Donnadieu, G. Bertrand, Chem. Commun. 2011, 47, 10614-10616; d) X. Xu, S. H. Kim, X. Zhang, A. K. Das, H. Hirao, S. H. Hong, Organometallics 2013, 32, 164-171; e) D. Mendoza-Espinosa, R. González-Olvera, G. E. Negrón-Silva, D. Angeles-Beltrán, O. R. Suárez-Castillo, A. Álvarez-Hernández, R. Santillan, Organometallics 2015, 34, 4529-4542; f) Y. Kim, E. Lee, Chem. Commun. 2016, 52 10922-10925; g) M. Flores-Jarillo, V. Salazar-Pereda, F. J. RuizMendoza, A. Alvarez-Hernández, O. R. Suarez-Castillo, D. MendozaEspinosa, Inorg. Chem. 2018, 57, 28-31.

[46] S. P. Nolan, Acc. Chem. Res. 2011, 44, 91-100.

[47] a) A. S. K. Hashmi, D. Riedel, M. Rudolph, F. Rominger, T. Oeser, Chem. Eur. J. 2012, 18, 3827-3830; b) R. Manzano, F. Rominger, A. S. K. Hashmi, Organometallics 2013, 32, 2199-2203; c) R. Manzano, T. Wurm, F. Rominger, Chem. Eur. J. 2014, 20, 6844-6848.

[48] W. Clegg, B. Conway, A. R. Kennedy, J. Klett, R. E. Mulvey, L. Russo, Eur. J. Inorg. Chem. 2011, 721-726.

[49] N. Mézailles, L. Ricard, F. Gagosz, Org. Lett., 7, 2005, 4133-4136.

[50] a) A. J. Arduengo III, R. Krafczyk, R. Schmutzler, Tetrahedron 1999, 55, 14523-14534; b) J. Huang, S. P. Nolan, J. Am. Chem. Soc. 1999, 121 9889-9890.

[51] CrysAlisPro; Oxford Diffraction: Oxford, UK 2008.

[52] G. M. Sheldrick, Acta Crystallogr., A64, 2008, 112-122. 
Entry for the Table of Contents (Please choose one layout)

Layout 2:

\section{FULL PAPER}

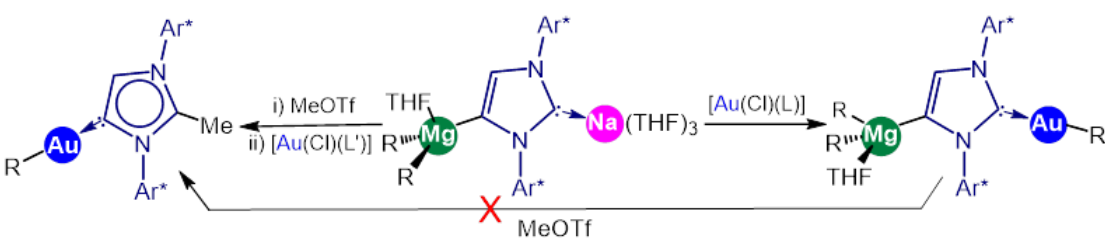

Normal or abnormal, it's still gold! Novel NHC stabilised Au(I) alkyl complexes have been accessed via a transmetallation approach based on a mixed $\mathrm{Na} / \mathrm{Mg}$ platform containing an anionic NHC as a precursor
A. Hernán-Gómez, M. Uzelac, S. E. Baillie, D. R. Armstrong, A. R. Kennedy, M. Á. Fuentes, and E. Hevia*

Page No. - Page No.

Molecular Manipulations of a Utility Nitrogen-Heterocyclic Carbene by Sodium Magnesiate Complexes and Transmetallation Chemistry with Gold Complexes 